\title{
Design and construction of an inverter using solar cell as a source of charger
}

\section{J. OlakunleC Oker* and B. Abdulrahaman O gunji}

Department of Science Laboratory Technology (Physics unit), Lagos State Polytechnic, Ikorodu, Lagos, NIGERIA "Corresponding author. E-mail: cokerclara@yahoo.com

Received:J une 20, 2012;Revised received:J anuary 5, 2013; Accepted:J anuary 28, 2013

Abstract: The present study is basically on electricity generation in which solar cell or module is used to power an inverter. This can also be called photovoltaic system, because it consists of solar modules, solar charge controller, 24V.d.c battery and an inverter. Solar modules serve as source of charger through solar charge controller to the battery and inverter are used in converting the direct current into an alternating current for the domestic appliance. This study is very useful in electricity generation especially in a developing country such as Nigeria where there is epileptic power supply. It-'s use is far better than generating set because it needs less maintenance, it does not use fuel, it is not heavy, it is rugged, it does not need an alternating current for its charging and it is noiseless.

Keywords: Battery, Electricity generation, Inverter, Solar cell, Solar charge controller

\section{INTRODUCTION}

Electricity generation is the first process in the delivery of electricity to consumers. The other processes are electric power transmission and electricity distribution. The importance of dependable electricity generation was revealed when it became apparent that electricity was useful for providing heat, light and power for human needs.

Electricity has been generated for the purpose of powering human technologies for at least 120 years from various sources of energy (Markvart, 2001).The first power plants were run on wood, while today, we rely mainly on petroleum, natural gas, coal, hydroelectric and nuclear power and a small amount of hydrogen, solar energy, tidal harness, wind generators and geothermal sources.In solar energy, sun has been worshipped as life - giver to our planet since ancient times.

The energy supply from the sun is truly enormous on average's the Earth's surface receives about $1.2 \times 10^{17} \mathrm{~W}$ of solar power (Kreider and Kreith, 1997). This means that in less than one hour enough energy is supplied to the Earth to satisfy the entire energy demand of the human population over the whole year. Indeed, it is the energy of sunlight assimilated by biological organisms over millions of years that has made possible the industrial growth as we know it today. Most of the other renewable means of power generation also depend on the sun as the primary source: hydroelectric, wind and wave power all have the same origin. Energy source such as photovoltaic are needed to help reduce the levels of green house gases in the atmosphere and alleviate this global warming.

Photovoltaic power generation is reliable, involve no moving parts, and the operation and maintenance costs are very low. The operation of a photovoltaic system is silent, and creates no atmospheric pollution photovoltaic systems are modular and can be quickly installed. Power can be generated where it is required without the need for transmission lines.Due to the erratic power supply in the country, which is becoming unbearable each day with its effect on the business and energy, solar cell powered inverter can be used as substitute where there is need for constant supply of power. Thus, the present was undertaken to use solar cell as source of charger to the accumulator powering an inverter and to use the inverter as A.C power source for domestic appliances.

Solar energy is the energy transmitted from the sun in the form of electromagnetic radiation, which requires no medium for its transmission (Coker, 2004). In 1861, Auguste Mouchout developed a steam engine powered entirely by the sun but its high costs coupled with the falling price of English coal doomed his invention to become a footnote in energy history.

In the United States, Swedish - born John Ericsson led efforts to harness solar power. He designed the "parabolic trough collector", a technology which functions more than a hundred years later on the same basic design.Solar power could boast few major gains through the first half of the $20^{\text {th }}$ century, though interst in a solar powered civilization never completely disappeared. Infact, Albert Einstein was awarded the 1921 Nobel prize in physics for his research on the photoelectric - a phenomenon central to the generation of electricity through solar cells. The term "photovoltaic" comes from the Greek (PV: photo meaning "light" and "voltaic", meaning electrical, from the name of the physicist Volta, after whom the 
measurement unit volts are named. The term "photovoltaic" has been in use in English since 1849.

However, huge PV market growth in Japan and Germany from the 1990s to the present has reenergized the solar industry. In 2002 Japan installed 25,00 solar roof tops such large PV orders are creating economies of scale thus steadily lowering costs (Erusiafe and Chendo, 2000). The PV market is currently growing at a blistering 30 percent per year with the promise of continually decreasing costs (Esper, 1998).

The most commonly known solar cell is configured as a large-area $p-n$ junction made from silicon. As a simplification, one can imagine bringing a layer of n-type silicon into direct contact with a layer of p-type silicon (Fig. 1). In practice, $p-n$ junctions of silicon solar cells are not made in this way, but rather, by diffusing an n-type doping into one side of a p-type wafer (or vice versa) (Duncan, 1997).
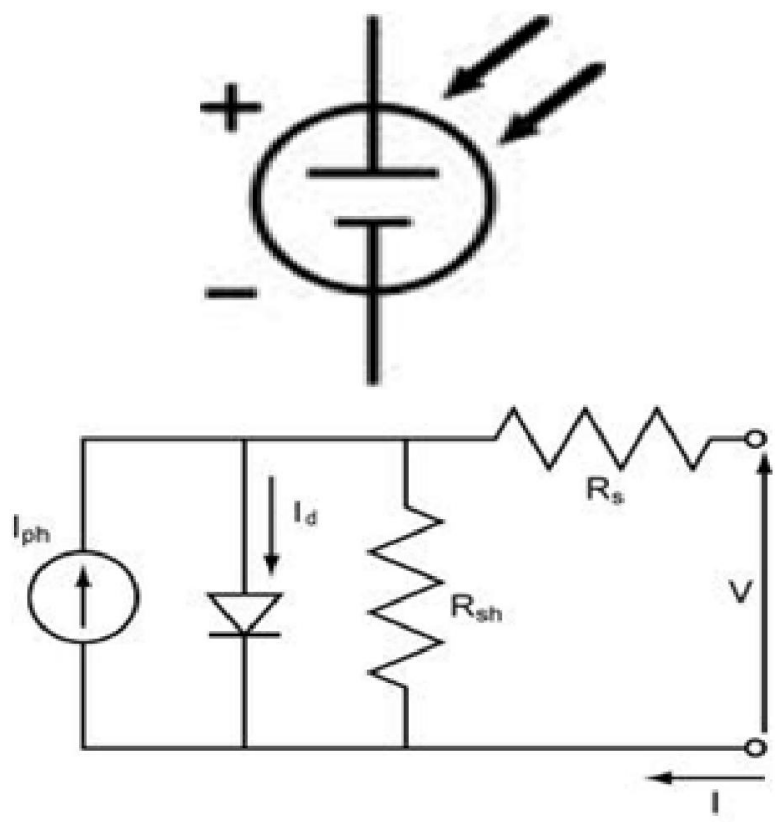

Fig. 1. Solar cell circuit and its equivalent diagram (Source: www.wikipedia/solarcell.com)

Theory

A solar cell's energy conversion efficiency (ç, "eta"), is the percentage of power converted (from absorbed light to electrical energy) and collected, when a solar cell is connected to an electrical circuit. This term is calculated using the ratio of $\mathrm{P}_{\mathrm{m}}$, divided by the input light irradiance under "standard" test conditions $(\mathrm{E}$, in W/ $\left.\mathrm{m}^{2}\right)$ and the surface area of the solar cell $\left(\mathrm{A}_{\mathrm{c}}\right.$ in $\left.\mathrm{m}^{2}\right)$.

$\eta=\frac{P_{m}}{E x \lambda_{r}}$

At solar noon on a clear March or September equinox day, the solar radiation at the equator is about $1000 \mathrm{~W} /$ $\mathrm{m}^{2}$. Hence, the "standard" solar radiation (known as the "air mass 1.5 spectrum") has a power density of 1000 watts per square meter. Thus, a $12 \%$ efficiency solar cell having $1 \mathrm{~m}^{2}$ of surface area in full sunlight at solar noon at the equator during either the March or September equinox will produce approximately 120 watts of peak power.

Another defining term in the overall behavior of a solar cell is the fill factor (FF). This is the ratio of the maximum power point divided by the open circuit voltage $(\mathrm{V} \alpha)$ and the short circuit current (I $\alpha)$ :

$F F=\frac{P_{m}}{V_{\alpha} x I_{\alpha}}=\frac{\eta x \lambda_{r} x E}{V_{\alpha} x I_{\propto}}$ Equation(2)

\section{MATERIALS AND METHODS}

A BP250/2 solar module is composed of individual solar cells. This crystalline silicon module type has an aluminium frame and glass on the front. In the field of photovoltaics, a solar module is a packaged interconnected assembly of solar cells. An installation of photovoltaic modules or panels is known as a photovoltaic array Fig. 2 .

PV Modules generate DC electrical energy when exposed to sunlight. Although single modules produce only a low voltage and current, shocks and burns are still a potential hazard. The shock hazard increases as modules are connected in series producing a higher voltage and the burn hazard increases as modules are connected in parallel producing higher current.

PV modules can be made safe to work on by fully converting the front surface with a dense opaque material such as the carton or placing module face down on a flat surface. A voltmeter can be used to verify that the output voltage is safe.

Most frequently, cells in a solar module are interconnected in series. The 3 BP 250/2 50Watts solar modules were connected in series so as to increase it output voltage and appropriate measurement were taken.

(a) Construction and mode of operation of solar charge controller: A solar charge controller limits the rate at which electric current is added or drawn from electric batteries. It prevents overcharging and may prevent against over voltage, which can reduce battery performance or lifespan and may pose safety risk. It may also prevent completely draining ("deep discharging") a battery, or perform controlled discharges depending on the battery technology to protect life.

The circuit shown in the Appendix A is a simple solar charge controller which stops charging the battery when they exceed a set high voltage level, and re-enable charging when battery voltage, drops back below that level.

(b) Construction of an inverter and mode of operation: This construction consist of different stages coupled together to perform a specific purpose and the circuit 
diagram were originally placed on breadboard and later transfered to the ferroboard for proper construction.

The circuit diagrams were shown in the Appendix B and the stages involved in the construction of the inverter include:

Sourcing stage

Regulating stage

Oscillating stage

Driving stage

Transformation stage

Output stage

Change-over stage

Battery charging stage

Sourcing stage: This stage consists mainly of direct current (D.C) battery and in this case is from Solar panel. The battery provides $24 \mathrm{~V}$ direct current (D.C) supply to the inverter system when the alternating current (A.C) from the main supply fails.

Regulating stage: The regulating stage consists of an IC voltage regulator. This is a three pin 9V IC voltage regulator. It is a simple precision regulator that regulates the supplied voltage down to $9 \mathrm{~V}$ from initial supply voltage of $24 \mathrm{~V}$ from the battery. The regulated voltage is then used by the oscillator to come on.

Oscillating stage: The oscillating stage is the heart of the inverter design. An oscillator is essentially an electronic circuit design to produce an alternating current signal of known frequency and wave form.

The inverter system needs to generate signal at a frequency of $50 \mathrm{~Hz}$. As a result, there has to be a kind of oscillator circuit for this to be achieved.

Here, a Pulse Width Modulation (PWM) regulator controller IC is used for the oscillator circuit. It is a common IC which has an internal RC (regulator controller) which could be made to oscillate to frequencies in excess of $1 \mathrm{MHz}$ depending on external component used. The IC contains various sections such as ERROR AMPLIFIER, SHUTDOWN ++5 V REGULATOR, COMPESATION and all of these are used to control the inverter.

The advantage of using the PWM regulator/controller $\mathrm{IC}$ is that it gives a low harmonic content in the frequency which is sui for the induction load. The PWM IC was 9V regulated supply voltage and generate signal at a frequency of $50 \mathrm{~Hz}$ which is sent to the driver for amplification through the pin 11 and 14 of IC.

Driving stage: The driving stage is required to drive the current derived from the output of the oscillator to the amplifier. The stage consists of Metallic Oxide Semiconductor Field Transistor (MOSFET) which has high impendence.

The transistor user are both PNP and NPN transistor which are connected in a push-pull arrangement.

The MOSFET driver stage does not match the oscillator to amplifier but also ensures that the stages of the
MOSFETs when in parallel are properly isolated from each other even if they are driven from the same source.

The MOSFET is driven by the signal output of the driving stage thus controlling the voltage at the gate of the MOSFETs which result in the MOSFETs channel being alternatively switch on and off. That is, when one second MOSFET channel switches on, the first MOSFET channel switches off.

The switching action of the MOSFET channel which is a crucial process in the outlet section is done repeatedly 50 turn per second, that is, at frequency of $50 \mathrm{~Hz}$.

Transformation stage: Here, a step-up transformer is used. It is a type transformer use for increasing voltage supply to a circuit. The step up transformer consists of two coils called the primary and secondary coils, wounded round a soft iron core that is made of sheets of soft iron. The secondary coil of this type of transformer is however greater than the number of turns in the primary coil.

The primary winding of this step-up transformer is $24 \mathrm{~V}$ $\mathrm{DV}-24 \mathrm{~V}$ and the secondary winding is a bifilar winding of $240 \mathrm{~V}$.

The alternating current which entered into each end of the primary winding induced a alternating current at $50 \mathrm{~Hz}$ in the secondary winding of the transformer and the alternating current voltage is stepped up by the transformer causing it to become $240 \mathrm{~V}$. The output voltage of the secondary winding is transferred to the socket outlet of the output of the inverter system.

O utput stage: In this stage, the A.C voltage produced by the inverter reaches output socket outlet. The voltage at this point is found to be $240 \mathrm{~V}$ alternating current and is kept constant by the action of the Pulse Width Modulation (PWM) of the IC. Also, the expected load is connected through this socket outlet so as to power it. Change-over stage: The change over stage takes the centre stage when the alternating current main power supply is off, then the yellow LED indicator comes on indicating that the inverter has started to operate on the battery mode and when the alternating current supply returns, the green LED indicator is on, then inverter

Table 1. Electrical characteristics of solar module BP 250/ 250w.

\begin{tabular}{lc}
\hline Typical data at standard temperature \\
conditions (STC) \\
\hline M odule type BP250/2 \\
Nominal peak power $\mathrm{P}_{\max }$ & $50.00 \mathrm{~W}$ \\
Peak power voltage $\mathrm{V}_{\mathrm{mp}}$ & $17.00 \mathrm{~V}$ \\
Peak power current $\mathrm{I}_{\mathrm{mp}}$ & $2.94 \mathrm{~A}$ \\
Short circuit current $\mathrm{I}_{\mathrm{sc}}$ & $3.22 \mathrm{~A}$ \\
Open circuit voltage $\mathrm{V}_{\text {oc }}$ & $21.20 \mathrm{~V}$ \\
Minimum power $\mathrm{P}_{\min }$ & $45.00 \mathrm{~W}$ \\
\hline
\end{tabular}


Table 2. Physical characteristics of solar module.

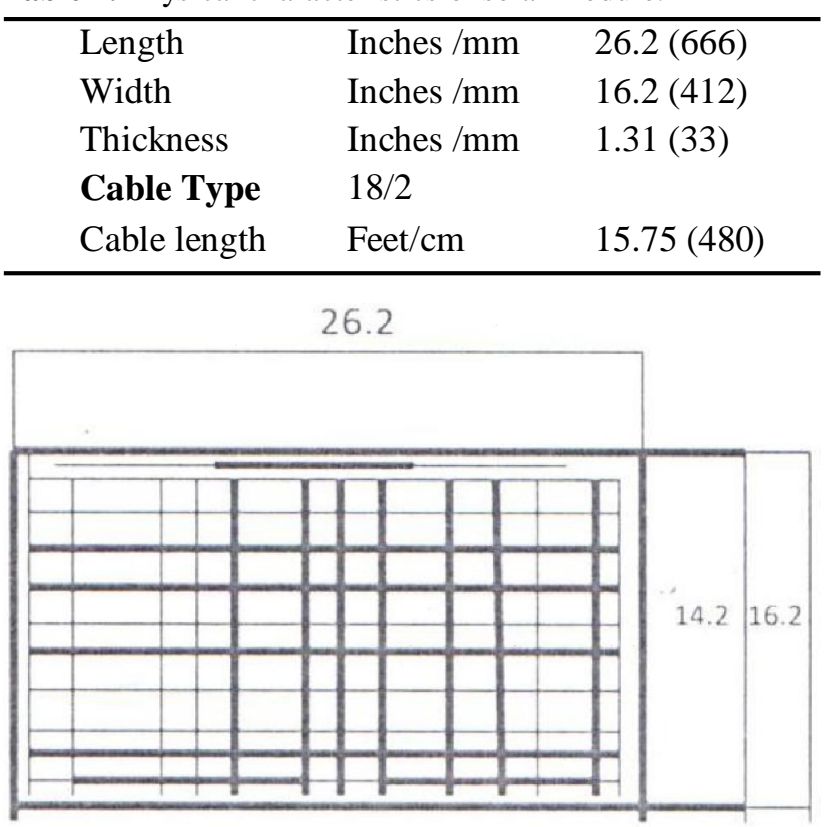

Fig.2 Sketch diagram of solar module.

automatically switches to the alternating current main supply mode and the battery charging process started. In this process, a three single pole relay is used for this stage such that it automatically switches from A.C mains to battery mode when it returns and stops drawing voltage from the battery hence, the A.V mains supply at the inverter system is directly sent to the inverter output socket.

Battery charging stage: The stage comprise of the

Table 3. Measurement and testing of an inverter and solar cell.

\begin{tabular}{lcc}
\hline M easurement & Specified & A chieved \\
\hline $\mathrm{V}_{\text {output }}$ (Solar cell) & $51 \mathrm{~V}$ & $51 \mathrm{~V}$ \\
$\mathrm{P}_{\text {output }}$ (Solar cell) & $150 \mathrm{~W}$ & $150 \mathrm{~W}$ \\
$\mathrm{~V}_{\text {output }}$ (Inveter) & $220 \mathrm{~V}$ & $220 \mathrm{~V}$ \\
$\mathrm{I}_{\text {output }}$ (Inverter) & $8 \mathrm{~A}$ & $8 \mathrm{~A}$ \\
$\mathrm{P}_{\text {output }}$ (Inveter) & $2 \mathrm{kVA}$ & $1.95 \mathrm{kVA}$ \\
Frequency & $50 \mathrm{~Hz}$ & $50 \mathrm{~Hz}$ \\
Waveform & sine wave & \\
\hline
\end{tabular}

Table 4. Loads to be used by the photovoltaic system.

\begin{tabular}{llccc}
\hline S. No. & Appliances & Units & Power/Wattage & Runtime \\
\hline 1 & Television & 2 & 50 & 9 Hours \\
2 & Home Theatre & 1 & 100 & 4.5 Hours \\
3 & Laptop & 1 & 30 & 9 Hours \\
4 & DVD Player & 1 & 11 & 3 Hours \\
5 & Bulbs & 10 & 9 & 12 Hours \\
6 & Fan & 2 & 11 & 12 Hours \\
7 & Blender & 1 & 30 & 15 Minutes \\
8 & Toaster & 1 & 500 & 10 Minutes \\
9 & DSTV & 1 & 12 & 4.5 Hours \\
10 & Washing machine & 1 & 400 & 1 Hour \\
\hline
\end{tabular}

transformation stage using a step down transformer and a rectifying stage. The step down transformer used, steps the main supply down from its initial $220 \mathrm{~V}$ to $24 \mathrm{~V}$ when the inverter is on main supply mode while the rectifier converts the voltage into D.C voltage. Thus, the battery is charged.

Other protection circuits: The other protection circuits used in the inverter system include:

a. Low battery shutdown circuit

b. Overload protection circuit

c. Trickling charging

L ow batter y shutdown cir cuit: The inverter gets it voltage and current from the battery. When the battery become discharge usually at $20 \mathrm{~V}$ which is below a set voltage. The inverter should switch off. However, if the inverter continues to draw from the discharged battery, the battery will get damaged.A low battery cut off circuit is used to switch off the inverter regarding this situation, by stopping the oscillating section. This sends shutdown pin 10 of the PWM controller IC.

After the construction of this inverter, the following testing and measurement were carried out and this is shown in the Table 3 .

\section{RESULTS AND DISCUSSION}

The solar panels were taken outside and aligned to receive near normal incident sunlight. The panels were connected to the charging circuit and the circuit was wired to the battery. Trickle charge was initiated and observation was made with constant $1 \mathrm{~A}$ throughout testing. The battery read $22.9 \mathrm{~V}$ before connection and then read $23.5 \mathrm{~V}$ once a connection was made. It potential the increased for the next 2 hours until the voltage stopped at $24 \mathrm{~V}$. AC Output voltage from the inverter is $220 \mathrm{~V}$, the waveform is sinewave and the frequency is 50 $\mathrm{Hz}$ respectively. It was observed that $2.5 \%$ of the total output power was lost during the testing and measurement, which may due to the components used for the construction (Figs. 3 and 4).

The energy injected into the electric grid by a Photovoltaic installation depends on the amount of power extracted 


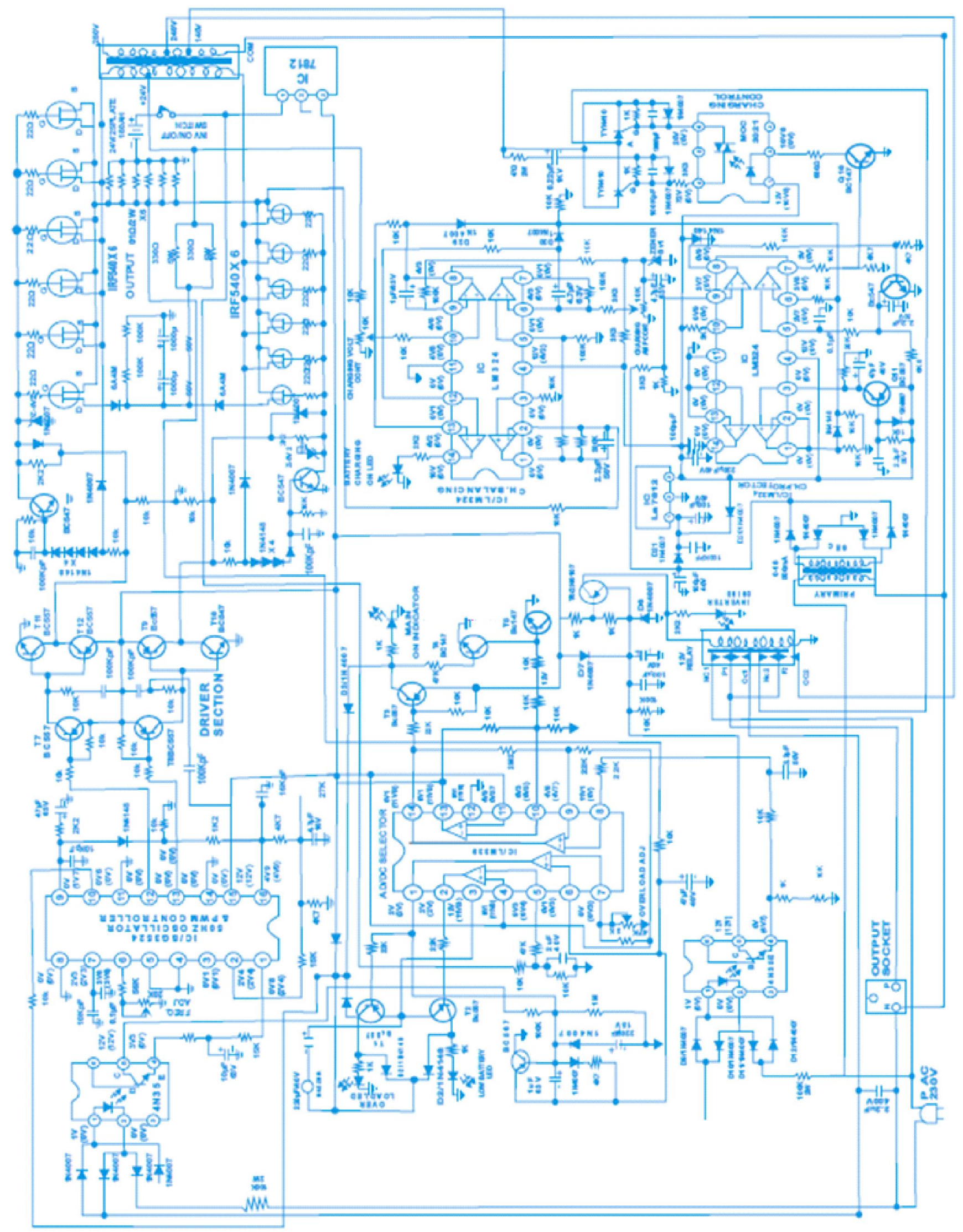

Fig. 3. 2000 Watt/24 volt with mosfet technology trickle charging 


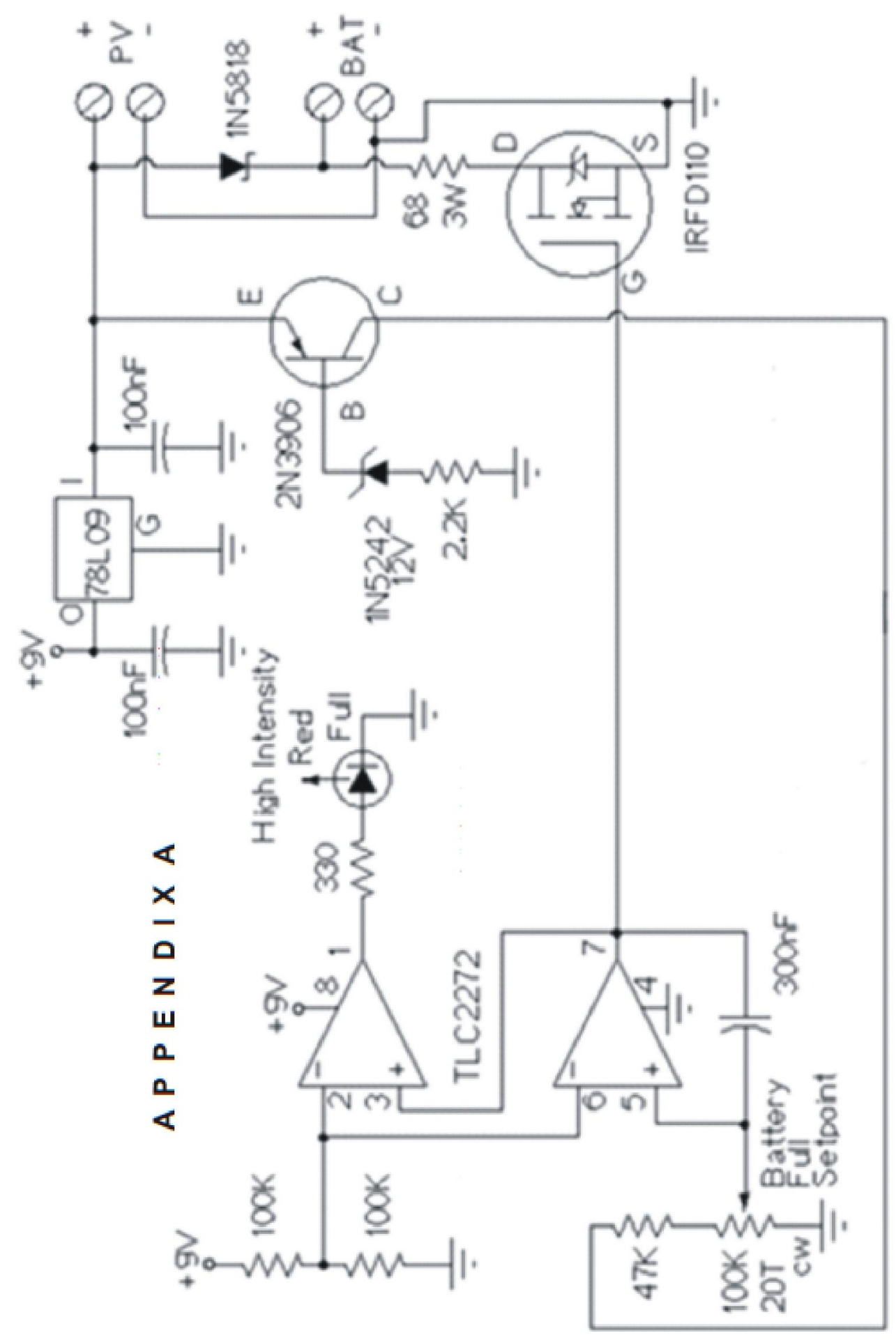


from the PV power source and the efficient processing of this power by the DC/AC inverter ( Eftichios et al., 2011). Economy of scale derived from the construction whereby power inverter less than 1KVA is transistor coupled and up to 5KVA is transistor or thyristor coupled transformer inverter system, while high power inverter more than $5 \mathrm{KVA}$ is constructed as thyristor bridge inverter system (Akinboro et al., 2012).

To test for the reliability and efficiency of this system, the following appliances were loaded on the system; the wattage and runtime used were recorded accordingly.

It can be shown that, if the battery is fully charged and the inverter is functioning well, the above listed appliances can be run successfully with the time.

\section{Conclusion}

The solar cell acted as a source of charger to the battery and inverting the power stored using an inverter into usable power for any load. The power output was usable for many domestic appliances that are sensitive to having sinusoidal inputs. However, further more research is needed on the production solar module and some other electronics components in Nigeria.

\section{REFERENCES}

Akinboro F.G, Adejumobi I.A and Erusiafeu, N. E.(2012). Design model considerations for grid connected Dc-Ac inverters transnational. J ournal of Science and Technology, 2 (3): 54-65

Coker, J.O. (2004). Solar energy and its applications in Nigeria. Global J ournal of Pure and Applied Sciences 10: 223 - 225.

Duncan, T. (1997). Electronics for today and tomorrow $2^{\text {nd }}$ Edition Hodder Education.

Eftichios,K and Frede, B (2011). Methods for the optimal design of grid-connected PV inverters. International J ournal of Renewable Energy Research, 1 (2): 54-64.

Erusiafe, N.E. and Chendo, M.A.C (2010). Size - prediction analysis for stand-alone photovoltaic system. Nigeria J ournal of Renewable Energy, 10: 15-27.

Esper A (1998). Solar energy, energy for biological system, Unesco/FAO working group $67-69$

Kreider J.F. and Kreith, F. (1977). Solar heating and cooling engineering, practical design and economics, $2^{\text {nd }}$ Edition Hemisphere Publishing Corporation Washington, D.C.

Markvart. T. (2001). Solar Electricity $2^{\text {nd }}$ Edition. Unesco Energy Engineering series Energy Engineering Learning/ Package. 